\title{
Early Childhood Education : In The Past, Present, and Future
}

\author{
Rina Syafrida ${ }^{1}$, Mimin Maryati ${ }^{2}$, Hinggil Permana ${ }^{3}$ \\ PIAUD, Fakultas Agama Islam, Universitas Singaperbangsa Karawang ${ }^{123}$ \\ rina.syafrida@fai.unsika.ac.id ${ }^{1}$, hinggil.permana@fai.unsika.ac.id ${ }^{3}$,
}

Info Artikel

Submitted: 27 August 2019

Accepted: 29 November 2019

Published: 03 Februari 2020

DOI: $10.26555 /$ jecce.v2i2.1016

Copyright (C) 2019 Universitas

Ahmad Dahlan

\section{Abstrak}

Penelitian ini bertujuan untuk menganalisis perkembangan pendidikan anak usia dini pada masa dulu ditinjau dari sejarah pendirian sebuah lembaga, perkembangan dan pelaksanaan pendidikan anak usia dini saat ini serta perkembangan pendidikan anak usia dini di masa yang akan datang dilihat berdasarkan analisis kebutuhan dan harapan dari orang tua dan pendidik. Penelitian dilaksanakan selama 3 bulan mulai Februari sampai April 2019 di lembaga Global Islamic School, di Jalan Raya Condet, Jakarta Timur. Metode penelitian adalah pendekatan kualitatif dengan strategi studi kasus yang bertujuan untuk melakukan penelitian kondisi objek yang alamiah, peneliti berperan sebagai instrumen kunci, teknik pengumpulan data secara triangulasi, analisis data bersifat induktif dan hasil penelitian kualitatif lebih menekankan makna dari pada generalisasi. Kesimpulan yang di dapat adalah Global Islamic School menggabungkan dua konsep utama yaitu pembentukan karakter seorang muslim dengan wawasan global dan menggabungkan 4 konsep fitrah anak yaitu olah qalbu, olah pikir, olah rasa dan olah raga dalam membantu anak mengembangkan potensi dan kemampuan.

Kata Kunci : Pendidikan Anak Usia Dini, Karakter Muslim, Konsep Fitrah

Abstract

This study aims to analyze the early childhood education development in the past in terms of the establishment history of an institution, the early childhood education development and implementation today and the early childhood education development in the future is seen based on the needs analysis and expectations of parents and educator. The study was conducted for 3 months from February to April 2019 at the Global Islamic School institution, on Jalan Raya Condet, East Jakarta. The research method is a qualitative approach with a case study strategy that aims to research natural object conditions, researchers act as key instruments, triangulation data collection techniques, inductive data analysis and qualitative research results emphasize more on meaning than generalization. The conclusion obtained is that the Global Islamic School combines two main concepts, namely the formation of the character of a Muslim with a global insight and combines the 4 concepts of the nature of the child, namely the heart, mind, exercise and feeling in helping children develop their potential and abilities.

Keywords : Early Childhood Education, Muslim Character, The Concept of Fitrah

\section{INTRODUCTION}

Lifelong education is an idiom popularized by experts who represent the meaning that the true education process never stops. Since the 15th century experts have begun to realize the importance of education from an early age. Since then many opinions and theories have developed about the importance of education from an early age and how it is implemented. Fredeiric Frobel, an expert born in Germany in 1782 who first introduced a kindergarten or playground. In Indonesia, Father of Education Ki Hadjar Dewantara introduced an educational concept for early childhood which was given the name of the student park. Not much different from the western world, Taman 
Siswa also emphasizes that children are whole human figures who are able to grow and develop well when given the opportunity and direction from the environment.

In Indonesian Government Regulation (PP) No. 66 of 2010 concerning the management and delivery of education can be elaborated if early childhood education can be done through various channels namely formal, non-formal, and or informal education. PAUD in formal education can take the form of kindergarten (TK), Raudatul Athfal (RA) or other forms of equals. Whereas for PAUD in non-formal education can be in the form of Play Groups (KB), Child Care Parks (TPA), or other equivalent forms. While for Early Childhood Education (PAUD) in informal education it can take the form of family education or education carried out by the environment such as Bina Keluarga Balita (BKB). Even the positive impact of PAUD is not only felt by children at this time, but also for their future. A study conducted by Barnett, W.S. in the United States in 1996 in Lives in the balance: Benefit-cost analysis of the Perry Preschool Program through age 27, showed that there were significant economic effects achieved by workers who took PAUD in their childhood compared to workers who did not attend PAUD.

Seeing how great the positive impact given by early childhood education, the government is increasingly with the growth and implementation of PAUD in Indonesia. The results of the Population Census in Indonesia in 2010 show data from 237,641,326 people in Indonesia, there are around 34.26 percent in the age range of $0-17$ years. While children aged 09 years amounted to $45.69 \%$. This data shows that more than one third of Indonesia's population are children. Data in 2011, which recorded only 14.8 percent of children 0-6 years old throughout Indonesia who just joined PAUD. While in rural areas there were only 12.6 percent who participated in PAUD, and in urban areas only slightly adrift was 17.1 percent. Many things have caused the low gross participation rate of children in PAUD. Parental awareness of the importance of PAUD is one of the most common causes. The minimum number of human resources both educators and education personnel who are qualified and understand the PAUD field is also one of the obstacles in the field. So that community access to be able to include their children in PAUD in the community is still very limited (Saipudin, 2010).

In addition, many discrepancies occur in the implementation of PAUD in the field with an initial vision that can occur due to several things. First is due to the lack of knowledge and understanding of PAUD organizers towards the goals of PAUD itself. As discussed above, the purpose of PAUD is to facilitate children to develop and build their own knowledge through a variety of fun activities. The focus of PAUD is not only to pursue achievement from the cognitive side, but also all aspects of a child's life including character, self-confidence, self-esteem, including the ability to know and follow the rules in society. Second, the occurrence of deviations in the purpose of PAUD is also due to demands from parents of students. Many parents who demand their children are able to master some abilities or skills at an early age such as the ability to read, write or count. This parental demand can occur because of the lack of information that comes to parents related to early childhood or because of the lack of parental involvement in the education process of their children in PAUD. In addition to the two factors that have been described, the factor of distrust of parents towards PAUD is now beginning to emerge. Some cases of violence against children occur in several schools or educational institutions that are rife lately, making parents hesitate to let go of their children (Sekretaris, Muslimat, \& Pusat, 2007). The impact of the number of cases, then came a new phenomenon that is parents looking for a trusted institution that is based on religious values adopted. At present, many early childhood education institutions based on Islam have been established. Global Islamic School is an educational institution that was built in 2002 which is committed to providing quality early childhood education. Based on the needs of children, GIS has become one of the institutions of early childhood education that has developed quite well and is in demand by parents. With a vision of optimizing the potential of children's nature, the Global Islamic School designed a curriculum based on moral development and noble character that was adjusted to local wisdom and global insights. 


\section{METHOD}

This research was conducted at the Global Islamic School, on Jalan Raya Condet, East Jakarta. This research was conducted for three months. The Global Islamic School School is located at Jalan Condet Raya no.5 Kramat Jati, the municipality of East Jakarta. Mr. H. B. Winarso is the founder of the Global Islamic School (GIS) campus foundation. The Global Islamic School (GIS) was first established in 2002. GIS is a global-minded Islamic school that was established to meet the needs and interests of Muslim students in Jakarta. In building and developing GIS, Mr. Warsono was not alone, he was always given input and advice from the Chancellor of UNJ and UIN. Specifically this study aims, namely: (1) Describing the history of the birth of early childhood education at the Global Islamic School. (2) Describe the implementation of early childhood education at Global Islamic School institutions. (3) Providing views on early childhood education in Indonesia in the future.

The method used in research at the Global Islamic School uses a qualitative approach with a case study strategy that aims to observe the condition of natural objects, researchers as key instruments, data collection techniques are carried out by triangulation, data analysis is inductive and qualitative research results emphasize the meaning of on generalization (sugiyono, 2016). The hidden meaning behind a phenomenon or event is the actual data, which contains a value behind the visible data. The selection of qualitative methods is also based on the consideration that using qualitative research will be able to provide detailed answers about the purpose of this study which is to search for, construct, and clarify the organization of early childhood education by the Global Islamic School in East Jakarta in 2019.

Data collection procedure is done after determining the location and situation information that is expected to provide information about the Global Islamic School institutions in the East Jakarta area. The main technique in data collection procedures in this study is through direct observation, participating researchers, and in-depth interviews and collecting various documents related to Global Islamic School institutions in the East Jakarta region. These three methods are commonly used in qualitative research. In order to get accurate and real data, researchers will be directly involved in the field and try to collect data that fits the focus of the research. Data analysis techniques used in this study include interview transcripts, data reduction, analysis, data interpretation and triangulation. From the results of data analysis, conclusions can be drawn.

\section{RESULT AND DISCUSSION}

Early childhood education has a main function which is to develop all aspects of child development namely cognitive, language, physical development in the form of gross and fine motor skills, social and emotional children (Pendidikan, Kebudayaan, \& Indonesia, 2014). The Ministry of National Education in 2002 set the objectives of the Early Childhood education program in Indonesia which is divided into two objectives namely general goals and special goals. The general objective of the PAUD program is to develop various potentials that exist in children from an early age as preparation for their lives and be able to adjust to the surrounding environment. While the purpose of educational activities in PAUD specifically aims: (a) Children are able to carry out worship, know and believe in God's creation and love fellow humans, (b) Children are able to manage body skills including movements that control body movements, subtle movements and movements abusive, and accepting sensory stimuli (five senses), (c) Children are able to use language for passive language understanding and can communicate effectively that are useful for thinking and learning (d) Children are able to think logically, critically, giving reasons, solving problems and finding causality. (e) Children are able to recognize the social environment, the role of society, and appreciate social and cultural diversity. (f) As well as being able to develop self-concepts, positive attitudes towards learning, self-control and a sense of belonging, Children have a sensitivity to rhythm, tone, barama, various sounds, clapping, and appreciating creative work (Lynn, Cuskelly, O'Callaghan, \& Gray, 2011).

The goal of early childhood learning at this time is to teach early childhood children for academic, intellectual, social, emotional and physical growth through a well-planned program of activities and experiences that have been prepared (Seefeldt, 2008). This early childhood education 
program aims to be able to help, direct and facilitate a child to be able to grow and develop optimally. Besides making them able to prepare themselves to socialize and enter the community (Katilmiş, Ekşi, \& Öztürk, 2011).

Based on the discussion above, hope all parties have the same view about what exactly the purpose of the implementation of education for early childhood. That education is held to facilitate and provide opportunities for children to develop optimally in their own way. Not demanding mastery of certain competencies that increasingly add to their developmental tasks or even burden them. According to Law No. 20 of 2003, early childhood education in Indonesia is carried out through three education channels namely formal, non-formal and informal.

Whereas there are four children in the sphere of early childhood education: (a) Infant, which is the period from when the child is born until the child is one year old. At this time the education provided is informal, namely the family as the main element of educators for the child. Another companion element that must be present besides the family is the doctor who is useful to oversee the health of the child. (b) Toddler The second period in the stage of the child's age is called toddler or more popular in Indonesia as a toddler (under three years). In this period children's education can be carried out informally without ignoring informal education. Non-formal education that can be enjoyed by children at this age is in the form of day care services. (c) Preschool At the age of four to six years the child is in the preschool period. At this time children can be included in non-formal institutions such as day care parks and playgroups. (d) Basic Education in Early Classes, Some early childhood education experts enter the age of elementary school early grades as early childhood. Although in Indonesia at this age children are no longer in the realm of early childhood education, but children should still be in a transition from kindergarten to elementary school. This period is the most sensitive period for children's development, teachers must be able to adjust learning provided to children selectively. After all, children just leave their fun activities in the nursery school, if the teacher in elementary school does not provide a pleasant learning experience at this time it will be embedded in the child that elementary school is scary (Engle, P. L., Black, M. M., Behrman, J. R., Cabral de Mello, M., Gertler, P. J., \& Kapiriri, 2007).

The Global Islamic School is an educational institution that combines the glory of Islamic values and the demands of globalization. The expected output is the birth of fully Indonesian people who are intelligent, skilled and cautious and competent in global competition. Efforts to achieve the goals of national education as well as the vision and mission of the Global Islamic School, we try to process the basic aspects of human beings, namely if the heart, if thought, if the taste and sports.

If the heart is a good moral education and noble character so that students have a superior personality and survive. This is a very basic and important part of education. In terms of education, it includes aspects of affection, namely how to build good-hearted people and good initiatives, this all depends or because it is based on good intentions, as contained in the Prophet's Hadith: "all deeds (deeds of deeds) depend on quality his intention "(Nawawi, 2010). Good intentions and positive will be able to make humans able to think positively and always desire to be better. This is what in popular terms today is called spiritual intelligence. Olah thought means building human beings to have independence and to master science and technology. Sports oriented to the development of people who are intelligent, creative, skilled in thinking and innovative. Exercise aims to produce people who are high in level of care, who are appreciative, sensitive, caring and able to express beauty and subtlety or we can call it Rahmatan lil'alamiin. This is very important because there will be no gratitude when someone does not have an appreciation of beauty and subtlety (Althof \& Berkowitz, 2006).

While sports is a process of human development so that it can make itself as a support for the functioning of the heart, heart, brain and taste (Akbar, 2014). Playgroup and Kindergarten is a form of pre-school education that is directed to help the physical and spiritual growth and development of students outside the family environment before entering the basic education level. That is the mirror of a whole person who uses his heart and mind to always dhikr to Allah, contemplates observing the universe, so that it comes to the conclusion that God created the universe not to play games, but with a very high and noble purpose of human life's purpose not only 
stop in this world, but hope and pray for a prosperous life in the hereafter. Pre-school education aims to help lay the foundation towards the development of attitudes, knowledge, skills, creativity needed by students in adjusting to the environment for growth and subsequent development Embed the basics of devotion in Allah SWT, as early as possible and in accordance with the demands of Al Qur'an and As-Sunnah with regard to the level of child development.

To achieve educational goals in Playgroup and Kindergarten, GIS strives for an appropriate learning system by paying attention to aspects of students' development, namely: Language, auditory memory, auditory observation, visual memory, visual observation, fine motor, gross motor, thinking skills and emotional social. GIS Have confidence that the first 12 years of a child's life is the most important stage of life in their growth and development. GIS strives to provide an educational platform that is compatible with universal Islamic values that are highly recommended in Islamic teachings to meet the needs of Islamic social and spiritual life.

The curriculum that is used as a reference for GIS is in accordance with what has been determined by the government, especially in this case the Ministry of Education, the KTSP curriculum, but GIS adds it or is mixed with curriculum from Malaysia and Singapore. GIS creates an educational curriculum that emphasizes learning processes that are suited to intellectual, physical, cultural, social and spiritual experiences. For the GIS religious curriculum, use the curriculum from EIBER (Malaysia), for English from Singapore and for mixed metematics from Malaysia and Singapore. Playgroup and Kindergarten believe that the basic life skills curriculum is a balance between a child's social life and Islamic spiritual values. Playgroup and Kindergarten curriculum is a series of learning approaches that are in line with children's learning outcomes in each subject, life skills, and morality in accordance with Islamic demands.

In curriculum development, Playgroup and Kindergarten Global Islamic School refers to the curriculum of the Ministry of National Education and the Islamic curriculum developed by the Center for Global Islamic School Curriculum Development. With the enactment of the TK Curriculum in 2010, it has implications for the learning approach model and assessment techniques. Assessment consists of external assessments and internal assessments. External assessment is an assessment carried out by other parties who do not carry out the learning process and is carried out by an institution, both domestic and foreign, intended among other things to control quality. Whereas internal assessment is an assessment that is planned and carried out by the teacher when the teaching and learning process takes place to guarantee the quality of learning.

Playgroup and Kindergarten Global Islamic School integrate academic and religious skills (spiritualisation) which are presented in two languages (bilingual) and assisted by native speakers. Academic skills based on the Ministry of National Education Curriculum, Ministry of Religion Curriculum and Curricula from various countries are summarized and adjusted so that it becomes a curriculum that is Global-minded and loaded with Islamic values or what we commonly call a curriculum characterized by PG-K GIS which is named Guidance for Educational Activities Centered Children.

The presentation is divided into three main activities, namely (a) Formation of behavior or Character Building through habituation to prepare children as early as possible to develop morals based on religious values which include: (1) Aqeedah (Faith); recognition of the existence of Allah SWT through His creation and His nature and some of the names of Allah (asmaaul husna). (2) Worship and the Qur'an; introduction to various prayer and fasting worship activities, introducing Iqro ', memorizing short surahs and daily prayers. (3) Morals; the introduction of various good deeds in relationships with parents, friends, teachers and the environment and giving alms (Baksos). (4) Cultivating national character values, including religious, honest, tolerance, discipline, hard work, creative, independent, democratic, curiosity, national spirit, love of the motherland, respect for achievement, friendly or communicative, peace-loving, fond of reading environmental care, social care, responsibility. (5) Healthy Living Habits and Maintaining Neatness by washing hands before and after eating, brushing teeth, taking out the trash in its place, tidying the place mat and cleaning the carpet after eating, tidying the locker before returning from school, working together to clean the classroom and toilet training. (b) Development of basic competencies or The Development of Basic 
Compentencies, presented through activities prepared by the teacher with the method of learning by doing so as to achieve certain ability targets and in accordance with the stages of child development while preparing for students to enter primary school.

The competencies developed are as follows: (1) Language ability includes listening, speaking, reading or writing, composing and memorizing. (2) Cognitive Ability or Thinking Skills include: mathematical logic, scientific basis, thinking knowledge and creativity. (3) Art and Craf include: fine motor and art creations. (4) Physical ability or physical development include: gross motor, balance, gymnastics or rhythmic, dancing, karate and various kinds of games. (5) Iqra', (6) Computers: practice fine motor skills and creative thinking, and introduce IT as early as possible. (7) Speak English: listening, speaking, reading, and writing. (8) Swimming: train the coordination of body balance, courage and be able to swim early stages. (c) The development of interests and talents, namely through supporting and extra-curricular activities, including: (1) extracurricular painting or drawing: training fine motor skills and developing creativity, daring to express the color and soul of art. (2) dance extracurricular: training fine and gross motor skills, developing the ability to coordinate motion and space, and the soul of art. (3) Karate extracurricular: training gross motor skills, balance and courage, (4) Pianic extracurricular: fostering the soul of art, recognizing tones gradually and sensitivity to music, training motor skills and auditory as well as systematic. (5) Vocal extracurricular activity: cultivates sensitivity to notes especially in simple songs, trains children's ability to recognize basic notes, trains auditory and courage.

The Global Islamic School was founded on the basis of strong parent involvement. In this regard, the school welcomes all forms of parental involvement with open arms and always motivates parents to take part in implementing educational activities. The best learning environment for children will be created if parents and schools work together. Schools expect good and productive collaboration between students, teachers and parents. BKOMG TK UNIT is carefully formed by parents and serves as a forum for partnerships between parents of students and teachers. Parents can provide support to students and teachers, discuss problems related to children, volunteer in school activities, attend various meetings, provide information to teachers or schools about matters relating to education.

Based on the description that has been described above, the researchers get a picture that the Global Islamic School was first established because of the concern of the founder of education in general. The founder saw the condition of the surrounding community who still did not care about the importance of education and access to education which was still very limited at that time. The founder, even though he did not have the basic skills in the field of education, ventured to open up educational services for local residents. With the assistance of a number of education experts from UNJ and UIN, GIS is now developing into an educational institution that has a far-reaching vision. GIS views that every child has the potential to become a leader or rahmatan lil 'alamin. The task of educators and educational institutions to accommodate children's potential in the right direction by utilizing available resources.

Learning conducted at the Global Islamic School tries to combine the development of the character of the nature of children with global insights so that children are expected to have strong characters and have broad insights and views on life and the world. GIS combines these two elements in curriculum development and describes them in daily learning. The Global Islamic School believes that the basic life skills curriculum is a balance between children's social life and Islamic spiritual values. Playgroup and Kindergarten curriculum is a series of learning approaches that are in line with children's learning outcomes in each subject, life skills, and morality in accordance with Islamic demands. Educators at GIS also view children as opening up a blank piece of paper that can be poured in anything but educators view the child as a human who has extraordinary potential. therefore in learning and interaction in school, educators position themselves as facilitators and motivators for children. Educators facilitate each child's potential to develop and be channeled well in a positive direction. Educators also provide motivation and enthusiasm and become good listeners for children, so that children feel valued and can have a good self-concept. 
In the global Islamic school, parents are involved in a number of learning activities in schools through events such as fathers day and muharam camp. In fathers day activities, involving parents, especially parents of men in special activities that have been designed by the school. This fathers day activity aims to encourage male parents to be aware of their role in the education of their children. So the role of fathers is not only to make a living, but also as a model for children. While in the muharam activities parents accompany children in welcoming the Islamic new year at school. In addition to the two activities above, there is also a parent parent meeting held by the school every month.

\section{CONCLUSION}

From the disscussion above, the conclusion and recommendation in this research explained as follows. The Global Islamic School is an early childhood education institution that was built since 2002. The Global Islamic School combines two main concepts, namely the formation of a Muslim's character with a global outlook. Then, the Global Islamic School combines a national curriculum that is combined with curriculums from Singapore and Malaysia that emphasize the learning process that is suited to intellectual, physical, cultural, social and spiritual experiences. The Global Islamic School combines 4 concepts of the nature of children, namely the heart, mind, exercise and feeling in helping children develop their potential and abilities. The cultivation of character in the learning and active involvement of parents is the main capital of the Global Islamic School as an international Islamic pilot school that can be used as a recommendation for other institutions in East Jakarta in the management of educational institutions for early childhood based on Islam.

In the other hand, recommendation of this research are: parents should be able to increase their active role in supporting programs created by schools so that there is a pattern of education that is in tune with the education at school and home education, educators are more honing their skills in creating educational innovations especially in instilling the character of early childhood, policy makers should prioritize the cultivation of character in institutions that conduct early childhood education, and the community should be able to make the Global Islamic School one of the choices of schools that prioritize the cultivation of children's character.

\section{REFERENCES}

Aitokhuehi, Oseghale, J., \& Ojogho, J. (2014, September). The Impact of Computer Literacy on Students' Academic Performance in Senior Secondary. Jurnal of Educational and Human Development, 3(3), 265 - 270. doi:10.15640/jehd.v3n3a21

Anderson, C. A. (1983). Computer Literacy: Changes for Teacher Education. Jurnal of Teacher Education, 6 - 9.

Astini, N. S. (2019). Pentingnya Literasi Teknologi Informasi dan Komunkasi Bagi Guru SD Untuk Menyiapkan Generasi Milenial. Seminar Nasional Dharma Arcaya Ke 1. Tantangan dan Peluang Dunia Pendidikan di Era 4.0 (pp. 113 - 120). Singaraja, Bali: STAHN Mpu Kuturan Singaraja.

Darmawan, J. (2018, November 28). https://aceh.tribunnews.com. Retrieved from www.serambinews.com: https://aceh.tribunnews.com/2018/11/27/menjadi-guru-erapendidikan-40

Dincer, S. (2016). Assesing Computer Literacy of University Graduates. The Third International Conference on Open and Flexxible Education (pp. 294 - 303). Hongkong: The Open University of Hongkong.

Djamarah, S. (2002). Rahasia Sukses Belajar. Jakarta: Rineka Cipta.

Hermanto, Marsudi, Subali, E., \& Hendrajati, E. (2018). Efektivitas TIK untuk Peningkatan Proses Belajar Mengajar di PAUD, TK dan Madrasah Diniyah "Mamba'ul Hisan Dusun Sekargadung, 
Desa Balerejo II, Kecamatan Panggungrejo, Kabupaten Blitar. SEMATEKSOS 3 "Strategi Pembangunan Nasional Menghadapu Revolusi Industri 4.0 (pp. 77 - 84). Surabaya: ITS.

Imam, F. N. (2015). Pemanfaatan TIK pada Pembelajaran Oleh Guru SMP Negeri 1 Ungaran Dalam Rangka Implementasi K13. Semarang: Universitas Negeri Semarang.

Malakauskienè, L., \& Šaparnienè, D. (2007). Computer Literacy in the Context of School as a Learning Organization. Social Research / Socialiniai tyrimai, 73 - 85.

Merkel, A. (2014, Februari 19). https://www.bundesregierung.de. Retrieved Oktober 03, 2019, from https://www.bundesregierung.de/breg-en/chancellor:

https://www.bundesregierung.de/breg-en/chancellor/speech-by-federal-chancellor-angelamerkel-to-the-oecd-conference-477432

Muthamainnah, I. (2016). Kesiapan Guru Kelas Menggunakan Media Teknologi Informasi dan Komunikasi (TIK) dalam Pembelajaran di Jakarta Selatan. Jakarta: UIN Syarif Hidayatullah Jakarta.

Nasution, L. H. (2013). Analisis Literasi Informasi Pengguna Perpustakaan Universitas Sumatra Utara. Bogor: Institut Pertanian Bogor.

Nurhayati, T. (2016). Probematika Guru dalam Menguasai TIK Pada Pembelajaran Pendidikan Agama Islam dan Solusinya di MI Al-Asy'ari Kuniran, Batangan Kabupaten Pati. Semarang: Universitas Negeri Walisongo.

Septina, R., \& Akbariansyah. (2019). Meningkatkan Profesionalisme Guru Dalam Menghadapi Tantangan Global di Era Revolusi Industri 4.0. Seminar Nasional Pendidikan (pp. 713 - 724). Palembang: Pasca Sarjana Universitas PGRI Palembang.

Sturges, P., \& Gastinger, A. ( 2010). Information Literacy as Human Right. Libri, 195-202. Retrieved from https://www.researchgate.net: https://www.researchgate.net/publication/259672528_Information_Literacy_as_a_Human_ Right

Tashakkori, A., \& Teddlie, C. (2010). Mixed Methodology. Mengombinasikan Pendeketan Kualitatif dan Kuantitatif. (B. P. Priadi, Trans.) California: Sage Publication. 